\title{
Compostos Fenólicos Extraídos do Farelo de Arroz Fermentado: Novos Conservantes Naturais
}

Anelise Christ-Ribeiro (I), Tania Becker-Algeri (I,II), Carolina da Silva Graça (I), Lidiane Moreira Chiattoni (I), Eliana Badiale-Furlong (I), Leonor Almeida de Souza Soares (I)

(I) FURG - Universidade Federal do Rio Grande (Avenida Itália, km 8. CEP 96203900 Bairro Carreiros - Rio Grande - RS), (II) UTFPR - Universidade Tecnologica Federal do Paraná (Avenida Brasil, 4232 CEP 85884-000 - Caixa Postal 271 - Medianeira - PR)

\section{Resumo}

Os conservantes químicos estão cada vez mais questionados sobre seu efeito nocivo nos alimentos, contudo são componentes indispensáveis para a preservação dos mesmos. Por isso, torna-se essencial a procura de compostos naturais que possam exercer a mesma função sem apresentarem os efeitos nocivos à saúde. Portanto, o objetivo do trabalho foi buscar novos conservantes naturais a partir do estudo de compostos fenólicos presentes na Spirulina sp. LEB-18 e no farelo de arroz fermentado por Rhizopus oryzae, comparando-os com o conservante químico, e estudá-los quanto ao seu efeito antifúngico (Penicillium verrucosum). Para a geração de biomassa foram adicionados ao farelo de arroz solução nutriente e a suspensão de esporos na concentração inicial de $4 \times 10^{6}$ esporos. ${ }^{-1}$ de farelo. As amostras foram incubadas a $30^{\circ} \mathrm{C}$. Os compostos fenólicos foram extraídos com metanol, da Spirulina sp. LEB-18 e da biomassa de farelo de arroz fermentado com Rhyzopus oryzae e quantificados colorimetricamente com reagente de Folin-Ciocalteau. A inibição fúngica foi avaliada em cultivo em placas de Petri, onde foi adicionado o meio BDA em conjunto com os diferentes tratamentos: controle - ágar BDA:água destilada (1:1 - v/v), extrato fenólico de Spirulina - ágar BDA:Fenol Spirulina (1:1- v/v), extrato fenólico de farelo de arroz- ágar BDA:Fenol de farelo de arroz fermentado (1:1 - v/v) e conservante químico - ágar BDA:propionato de cálcio (1:1 - v/v). Após solidificação, os meios 
foram inoculados com o fungo Penicillium verrucosum, no centro das placas, na concentração de $4 \times 10^{6}$ esporos. $\mathrm{mL}^{-1}$ e estas incubadas em câmara de fermentação a $25^{\circ} \mathrm{C}$. O crescimento fúngico foi avaliado no $2^{\circ}$, $3^{\circ}, 5^{\circ}, 7^{\circ}$ e $9^{\circ}$ dias através de medidas ortogonais do diâmetro do micélio e as placas dos testes foram fotografadas para análise visual do crescimento fúngico. $\mathrm{O}$ tratamento que obteve a maior inibição fúngica, tanto no $1^{\circ}$ como no $9^{\circ}$ dia, foi o de compostos fenólicos de farelo de arroz. Os tratamentos controle seguido do propionato de cálcio foram os que apresentaram os maiores crescimentos fúngicos, mostrando uma menor ação do conservador químico na barreira para o desenvolvimento de microorganismos. Enquanto que o tratamento com os compostos fenólicos extraídos do farelo de arroz fermentado foi o que apresentou a maior inibição fúngica, seguido dos compostos fenólicos de Spirulina.

Palavras-Chave: Antifúngico, Arroz, Microalga Agência de Fomento: 